BMJ Open Respiratory Research

\title{
Global Asthma Network Phase I study in Mexico: prevalence of asthma symptoms, risk factors and altitude associations - a cross-sectional study
}

Blanca Estela Del-Río-Navarro, ${ }^{1}$ Arturo Berber, ${ }^{1}$ Nayely Reyes-Noriega (D) , ${ }^{1}$ Elsy Maureen Navarrete-Rodríguez, ${ }^{1}$ Roberto García-Almaraz, ${ }^{2}$ Philippa Ellwood, ${ }^{3}$ Luis Garcia-Marcos, ${ }^{4}$ Omar Josué Saucedo-Ramírez, ${ }^{1}$ Valente Juan Mérida-Palacio, ${ }^{5}$ Beatriz Del Carmen Ramos-García, ${ }^{6}$ Alberto José Escalante-Domínguez, ${ }^{7}$ Francisco Javier Linares-Zapién, ${ }^{8}$ Héctor Leonardo Moreno-Gardea, ${ }^{9}$ Georgina Ochoa-López, ${ }^{10}$ Luis Octavio Hernández-Mondragón, ${ }^{11}$ José Santos Lozano-Sáenz, ${ }^{12}$ José Antonio Sacre-Hazouri, ${ }^{13}$ Ángeles Juan-Pineda, ${ }^{14}$ Ma Guadalupe Sánchez-Coronel, ${ }^{15}$ Noel Rodríguez-Pérez, ${ }^{15}$ María de Jesús Ambriz-Moreno, ${ }^{16}$ The GAN Phase I group

To cite: Del-Río-Navarro BE, Berber A, Reyes-Noriega N, et al. Global Asthma Network Phase I study in Mexico: prevalence of asthma symptoms, risk factors and altitude associations-a cross-sectional study. BMJ Open Resp Res 2020;7:e000658. doi:10.1136/ bmjresp-2020-000658

Received 2 June 2020 Revised 12 November 2020 Accepted 17 November 2020

D Check for updates

(C) Author(s) (or their employer(s)) 2020. Re-use permitted under CC BY-NC. No commercial re-use. See rights and permissions. Published by BMJ.

For numbered affiliations see end of article.

Correspondence to Dr Nayely Reyes-Noriega; naye.rey.nor@gmail.com

\section{ABSTRACT}

Background Global Asthma Network (GAN) was established in 2012 as a development to the International Study of Asthma and Allergies in Childhood to improve asthma care globally.

Objective To survey asthma, allergic rhinitis and atopic dermatitis in primary and secondary school children and to investigate and evaluate its prevalence, severity, management and risk factors in Mexico.

Methods GAN Phase I is a cross-sectional, multicentre survey carried out in 15 centres corresponding to 14 Mexican cities throughout 20162019 using the validated Spanish language version of the GAN Phase I questionnaires. The questionnaires were completed by parents of 6-7-year-old primary school pupils (school children) and by 13-14-year-old adolescents.

Results A total of 35780 school children and 41399 adolescents participated. Wheezing ever prevalence was $26.2 \%(95 \% \mathrm{Cl} 25.8 \%$ to $26.7 \%)$ in school children and $23.9 \%(95 \% \mathrm{Cl} 23.4 \%$ to $24.3 \%)$ in adolescents. The corresponding frequencies for current wheeze were $10.2 \%(95 \% \mathrm{Cl} 9.9 \%$ to $10.5 \%)$ and $11.6 \%(95 \% \mathrm{Cl}$ $11.2 \%$ to $11.9 \%$ ). In school children, the risk factors for current wheeze were rhinitis (OR 4.484; $95 \% \mathrm{Cl} 3.915 \%$ to $5.134 \%$ ) and rash symptoms (OR 1.735; 95\% Cl 1.461\% to $2.059 \%$ ). For adolescents, rhinitis symptoms (OR 3.492; $95 \% \mathrm{Cl} 3.188 \%$ to $3.825 \%$ ) and allergic rhinitis diagnosis (OR 2.144; $95 \% \mathrm{Cl} 1.787 \%$ to $2.572 \%$ ) were the most significant. For both groups, there was a negative relation with centres' sea level altitude higher than $1500 \mathrm{~m}$ above mean sea level $(p<0.005)$.

Conclusions The most important risk factors for asthma symptoms in both age groups were the presence of rhinitis and rash symptoms or diagnosis. On the other hand, sea level altitude higher than 1500 metres was a protective factor.

Key messages
What are the characteristics of asthma in school
children and adolescents according to Global Asthma
Network methodology in Mexico?
The last large epidemiological asthma study in
Mexico was conducted in 2003 in five centres, but
the published reports were not complete.
The regional variations of asthma in Mexico are de-
scribed, as well as significant risk factors. A negative
association between altitude and current asthma
symptoms is identified.

\section{INTRODUCTION}

Asthma is a significant public health problem. It is estimated that 339 million people suffer from this chronic disease in the world and that the daily number of deaths due to asthma is around $1150 .^{2}$ Worldwide, there were 10.5 million years of life lost (due to premature death) attributed to asthmarelated premature deaths in 2016. ${ }^{1}$ Globally, it was estimated that the costs associated with asthma exceeded those of tuberculosis and HIV/AIDS combined and the burden of asthma is relevant for the health system in terms of both direct (hospitalisation and treatment) and indirect costs (absenteeism in school and work for the parents). ${ }^{3}$

Therefore, significant efforts have been made to assess and compare the prevalence of asthma in different countries around the world, including the factors associated with 
asthma symptoms. For instance, the Global Asthma Network (GAN) was established in 2012 as an evolution of the International Study of Asthma and Allergies in Childhood (ISAAC) to improve asthma care globally, with a focus on low-income and middle-income countries (http://www.globalasthmanetwork.org/). ISAAC was carried out in three phases. ISAAC Phase One (19941995) used a written questionnaire for school children and adolescents in 56 countries and demonstrated a large variation in the prevalence of asthma symptoms in children in different geographical locales, including unstudied populations. ${ }^{4}$ ISAAC Phase Three (2001-2003) described asthma prevalence and severity of 237 study centres. Ninety-eight countries not previously considered for ISAAC Phase One were included. According to the global ISAAC Phase Three results, the highest prevalence of asthma in adolescents $(\geq 20 \%)$ was generally observed in English speaking countries of Australasia, Europe and North America, and in parts of Latin America (http:// isaac.auckland.ac.nz/phases/phases.html). ${ }^{15}$ GAN used the same methodology used in ISAAC Phases One and Three. However, questions regarding risk factors and management of asthma were added. ${ }^{6}$

According to ISAAC Phase Three in Mexico, where ten centres from eight cities participated, the prevalence of current wheezing (wheezing in the past 12 months) in adolescents ranged from $3.9 \%$ in Mexico City to $14.4 \%$ in Victoria City, Tamaulipas. ${ }^{6}$ Additionally, the asthma risk factors in Mexico City were identified using data from ISAAC Phase Three. The most important risk factors for current wheeze were rhinitis and eczema symptoms, as well as early and current use of paracetamol and antibiotics in school children and adolescents. Maternal contact with farm animals in men aged 6-7 and smoking in men and women aged 13-14 were also risk factors for current wheeze. ${ }^{7}$

The aims of GAN Phase I are to survey asthma, allergic rhinitis and atopic dermatitis in school children and adolescents from different countries, to investigate and evaluate the prevalence, severity, management and risk factors in reference to ISAAC Phase Three. Furthermore, the correct management of asthma, and access to essential asthma treatments are assessed. ${ }^{5}$

\section{PATIENTS AND METHODS}

GAN Phase I is a cross-sectional, multicentre, international, epidemiological research study. Primary and secondary schools were randomly selected from a list of public and private institutions per centre to represent the target population. This phase included 15 centres in 14 cities of Mexico, including Puerto Vallarta (Vall, $7 \mathrm{~m}$ above mean sea level (mamsl)), Matamoros (Mat, 8 mamsl), Mexicali (Mexi, 8 mamsl), Tijuana (Tij, 20 mamsl), Victoria City (CdVt, 316 mamsl), Cordoba (Cor, 860 mamsl), Juarez City (CdJz, 1120 mamsl), Chihuahua City (Chi, 1413 mamsl), Xalapa (Xal, 1417 mamsl), San Luis Potosi (SLP, 1864 mamsl), Aguascalientes (AgCa,
1888 mamsl), Morelia (Mor, 1920 mamsl), Mexico City (CdMx, 2250 mamsl), urban Toluca (ToUr, 2667 mamsl) and rural Toluca (ToRu, 2667 mamsl). The study was carried out in 6-7years old (school children) where parents completed the questionnaires and 13-14years old (adolescents) who self-completed questionnaires at school. In both age groups, parents granted written informed consent.

Details on the GAN methodology can be found in its corresponding manual (http://www.globalasthmanetwork.org/surveillance/manual/manual.php; accessed on 23 March 2020).

GAN used the same standardised written core questionnaires developed for ISAAC Phases One and Three, with the addition of doctor confirmed diagnosis of asthma, hay fever and eczema. In Mexico, the questionnaires were translated and back-translated from English to Spanish by three independent linguistic professionals, following the ISAAC English language questionnaire translation guidelines, to ensure that they had the same structure and logic as the original. ${ }^{8}$ Once the Spanish version of each questionnaire was finalised, a pilot test was carried out in school children and adolescents in Mexico City. It is worth mentioning that all the centres involved in this study applied the same version of the questionnaire by age group.

The written questionnaires focus on demographics and anthropometric characteristics such as age, date of birth, sex, school and date of interview, as well as questions on prevalence and severity of asthma, asthma management and risk factors like the use of paracetamol, antibiotics, physical activity, food consumption and air pollution. Questionnaires were coded using a unique number for each centre, school, and participant to ensure confidentiality. Also, height and weight measurements were taken by fieldworkers in schools.

Complete questionnaires for each group could be consulted in online (http://www.globalasthmanetwork. org/surveillance/manual/study6.php and http:// www.globalasthmanetwork.org/surveillance/manual/ study13.php (accessed on 23 March 2020)).

\section{DEFINITIONS}

The standardised questions used in ISAAC Phase Three and GAN Phase I for asthma and asthma symptoms are:

1. Have you (has your child) ever had wheezing or whistling in the chest at any time in the past? (WHEZEEV).

2. Have you (has your child) had wheezing or whistling in the chest in the past 12 months? (WHEZ12).

3 . In the past 12 months, has wheezing ever been severe enough to limit your (your child's) speech to only one or two words at a time between breaths? (SPEECH12).

4. In the past 12 months, how often, on average, has your (has this child's) sleep been disturbed due to wheezing? (AWAKE12).

5. How many attacks of wheezing have you (has this child) had in the past 12 months? (NWHEZ12). 
6. Have you (has your child) ever had asthma? (ASTHMAEV).

7. Was your (this child's) asthma confirmed by a doctor? (ASTHDOC).

8. Do you (Does this child) have a written plan which tells you how to look after your asthma? (ASTHPLAN).

In this study, question 1 was used to estimate the cumulative prevalence of wheeze. Question 2 estimated the prevalence of current asthma symptoms, positive answers to question 2 and questions 3, 4 and 5 were used to estimate the prevalence of severe asthma symptoms. Question 6 was used to estimate the prevalence of asthma ever; question 7 was used to estimate the prevalence of asthma diagnosed by a doctor and question 8 was used to estimate the prevalence of a medical plan for asthma symptoms. ${ }^{5}$

\section{SAMPLE SIZE}

A sample size of 3000 participants per age group per centre was used, assuming no cluster sampling effect. The sample size provided significance greater than $99 \%$ (at the 1\% level of significance) to detect differences in prevalence. The average expected participation was at least $80 \%$ for adolescents and $70 \%$ for children. ${ }^{5}$

\section{DATA COLLECTION AND ANALYSIS}

Data were entered on an electronic database by the medical personnel of study centres from October 2015 to December 2019. Ten per cent of questionnaires were double entered to mitigate possible errors. GAN databases were checked and approved in 2019, by Murcia's (Spain) data centre, which was responsible for the quality control of the Spanish-speaking and Portuguesespeaking centres. Each centre had to complete a detailed Centre Report verifying compliance with the methodological standards established by ISAAC and GAN. The report requested a description of the sampling frame, the school selection method, the number of schools included, excluded and rejected, the participant selection method and data entry, the record of changes made to the data, the number of children and adolescents who participated and refused, as well as a map of the sampling frame of the study area. ${ }^{9}$

Data analysis included central tendency measurements (mean, SD and 95\% CI), as well as the prevalence of asthma symptoms, severity and asthma diagnosed by a doctor.

Current asthma symptoms (WHEZ12) was the dependent variable in the analyses examining the risk factors for asthma. All possible factors which were likely to influence the prevalence of current wheeze were identified $(p<0.05)$ by the Fisher and $\chi^{2}$ tests. These factors were further analysed by backward conditional logistic regression to create models to predict current wheeze.

Microsoft Excel 2016 V.16.0.6568.2036 was used to organise data and IBM SPSS Statistics V.25.0 for statistical analysis.

\section{PATIENT AND PUBLIC INVOLVEMENT}

Since this study strictly relied on existing data via an approved written consent, we did not engage with patient stakeholders in the design or conduct of the analyses nor interpretation of the findings.

\section{RESULTS}

The response rate of the delivered questionnaires was $88.34 \%$ for school children and $91.53 \%$ for adolescents.

In both age groups, 15 centres participated. A total of 570 schools were included in the 6-7 group, with a total of 35780 school children. In the 13-14 group, 220 schools were included with a total of 41399 adolescents.

The prevalence of wheezing ever, current asthma symptoms and severity of symptoms related to asthma are presented in table 1. Cumulative prevalence of wheeze and the prevalence of current asthma symptoms were higher in men in the school children group. Nonetheless, in the adolescent group, these prevalences were higher in women.

One-third of school children with a history of 'wheezing ever' started in the first year of life and just over $25 \%$ after 5 years of age. Among school children, $50 \%$ had wheezed 1-3 times (more men than women) and 10\% had 4-12 episodes of wheezing in the past year. In the female adolescent group and among those current wheezers, almost $50 \%$ had 1-3 episodes of wheezing and, 9\% reported 4-12 episodes of current wheezing.

Severe asthma symptoms (defined as waking up at night due to wheezing at least one or more times per week and any episode of wheeze severe enough to limit the ability to speak in the past year) were present in more than $30 \%$ of both men and women in the school children group and $25 \%$ of women in the adolescent group, among those with current wheezing.

Despite the somewhat high prevalence of asthma symptoms $(9 \%-13.6 \%)$, only $6 \%-9 \%$ of school children and adolescents had received a medical diagnosis of asthma and, less than $5 \%$ had a written plan of action in case of asthma symptoms.

Tables 2 and 3 show the risk factors for asthma symptoms in the school children and adolescent groups, respectively. The most significant associations were the presence of rhinitis and rash symptoms in the past 12 months, the previous diagnosis of allergic rhinitis or atopic dermatitis, as well as the use of paracetamol in the past 12 months in both groups. Early pneumonia history and wheeze in the first year of life were important factors in the school children group.

Asthma symptoms in the female school children group were significantly associated with a maternal history of smoking during pregnancy and contact with farm animals in the first year of life. Additionally, in the female adolescent group, the presence of asthma symptoms was significantly associated with occasional smoking. On the other hand, there was a negative association between the altitude of the centres and the presence of current wheeze in both the school children and adolescent groups. 
Table 1 Prevalence and severity of asthma symptoms in school children and adolescents from 15 centres of Mexico according to Global Asthma Network 2019

\begin{tabular}{|c|c|c|c|c|c|c|}
\hline \multirow[b]{2}{*}{ Variable } & \multicolumn{3}{|c|}{ Children 6-7 years old } & \multicolumn{3}{|c|}{ Teenagers $13-14$ years old } \\
\hline & $\mathbf{N}$ & $\begin{array}{l}\text { Frequency } \\
\%\end{array}$ & $95 \% \mathrm{Cl}$ & $\mathbf{N}$ & $\begin{array}{l}\text { Frequency } \\
\%\end{array}$ & $95 \% \mathrm{Cl}$ \\
\hline Males & $4883 / 16971$ & 28.8 & 28.1 to 29.5 & $4153 / 19665$ & 21.1 & 20.5 to 21.7 \\
\hline Females & $4321 / 18143$ & 23.8 & 23.2 to 24.4 & $5608 / 21254$ & 26.4 & 25.8 to 27.0 \\
\hline Total & $9204 / 35114$ & 26.2 & 25.8 to 26.7 & $9761 / 40919$ & 23.9 & 23.4 to 24.3 \\
\hline Males & $1712 / 4757$ & 36.0 & 34.6 to 37.4 & NA & & \\
\hline Females & $1334 / 4234$ & 31.5 & 30.1 to 32.9 & NA & & \\
\hline Total & $3046 / 8991$ & 33.9 & 32.9 to 34.9 & NA & & \\
\hline \multicolumn{7}{|c|}{$\begin{array}{l}\text { Whezage } \\
1-2 \text { years old }\end{array}$} \\
\hline Total & $2380 / 8991$ & 26.5 & 25.6 to 27.4 & NA & & \\
\hline \multicolumn{7}{|c|}{$\begin{array}{l}\text { Whezage } \\
3-4 \text { years old }\end{array}$} \\
\hline Males & $183 / 4757$ & 3.8 & 3.3 to 4.4 & NA & & \\
\hline Females & $182 / 4234$ & 4.3 & 3.7 to 4.9 & NA & & \\
\hline Total & $365 / 8991$ & 4.1 & 3.7 to 4.5 & NA & & \\
\hline \multicolumn{7}{|c|}{$\begin{array}{l}\text { Whezage } \\
5-6 \text { years old }\end{array}$} \\
\hline Males & $1280 / 4757$ & 26.9 & 25.6 to 28.2 & NA & & \\
\hline Females & $1113 / 4234$ & 26.3 & 25.0 to 27.6 & NA & & \\
\hline \multicolumn{7}{|c|}{$\begin{array}{l}\text { WHEZ12 } \\
\text { (current wheeze) }\end{array}$} \\
\hline Males & $1955 / 17043$ & 11.5 & 11.0 to 11.9 & $1847 / 19726$ & 9.4 & 9.0 to 9.8 \\
\hline Females & $1642 / 18215$ & 9.0 & 8.6 to 9.4 & 2898/21328 & 13.6 & 13.1 to 14.0 \\
\hline Total & $3597 / 35258$ & 10.2 & 9.9 to 10.5 & $4745 / 41054$ & 11.6 & 11.2 to 11.9 \\
\hline \multicolumn{7}{|l|}{$\begin{array}{l}\text { NWHEZ12 } \\
0\end{array}$} \\
\hline Males & $766 / 2682$ & 28.6 & 26.9 to 30.3 & $2108 / 3774$ & 55.9 & 54.3 to 57.4 \\
\hline Females & $824 / 2434$ & 33.9 & 32.0 to 35.7 & $1888 / 4555$ & 41.4 & 40.0 to 42.9 \\
\hline Total & $1590 / 5116$ & 31.1 & 29.8 to 32.3 & $3996 / 8329$ & 47.9 & 46.9 to 49.0 \\
\hline \multicolumn{7}{|l|}{$\begin{array}{l}\text { NWHEZ12 } \\
1-3\end{array}$} \\
\hline Males & $1593 / 2682$ & 59.4 & 57.5 to 61.3 & $1338 / 3774$ & 35.5 & 33.9 to 37.0 \\
\hline Females & $1326 / 2434$ & 54.5 & 52.5 to 56.5 & $2163 / 4555$ & 47.5 & 46.0 to 48.9 \\
\hline Total & $2919 / 5116$ & 57.1 & 55.7 to 58.4 & $3501 / 8329$ & 42.0 & 41.0 to 43.1 \\
\hline \multicolumn{7}{|l|}{$\begin{array}{l}\text { NWHEZ12 } \\
4-12\end{array}$} \\
\hline Males & $272 / 2682$ & 10.1 & 9.0 to 11.3 & $257 / 3774$ & 6.8 & 6.0 to 7.6 \\
\hline
\end{tabular}


Table 1 Continued

\begin{tabular}{|c|c|c|c|c|c|c|}
\hline \multirow[b]{2}{*}{ Variable } & \multicolumn{3}{|c|}{ Children 6-7 years old } & \multicolumn{3}{|c|}{ Teenagers $13-14$ years old } \\
\hline & $\mathbf{N}$ & $\begin{array}{l}\text { Frequency } \\
\%\end{array}$ & $95 \% \mathrm{Cl}$ & $\mathbf{N}$ & $\begin{array}{l}\text { Frequency } \\
\%\end{array}$ & $95 \% \mathrm{Cl}$ \\
\hline Females & $250 / 2434$ & 10.3 & 9.1 to 11.5 & $422 / 4555$ & 9.3 & 8.4 to 10.1 \\
\hline Total & $522 / 5116$ & 10.2 & 9.4 to 11.0 & $679 / 8329$ & 8.2 & 7.6 to 8.7 \\
\hline \multicolumn{7}{|l|}{$\begin{array}{l}\text { NWHEZ12 } \\
>12\end{array}$} \\
\hline Males & $51 / 2682$ & 1.9 & 1.4 to 2.4 & $71 / 3774$ & 1.9 & 1.4 to 2.3 \\
\hline Females & $34 / 2434$ & 1.4 & 0.9 to 1.9 & $82 / 4555$ & 1.8 & 1.4 to 2.2 \\
\hline Total & $85 / 5116$ & 1.7 & 1.3 to 2.0 & $153 / 8329$ & 1.8 & 1.5 to 2.1 \\
\hline \multicolumn{7}{|l|}{$\begin{array}{l}\text { AWAKE12 } \\
\text { never }\end{array}$} \\
\hline Males & $1386 / 2600$ & 53.3 & 51.4 to 55.2 & $3052 / 3906$ & 78.1 & 76.8 to 79.4 \\
\hline Females & $1296 / 2345$ & 55.3 & 53.2 to 57.3 & $2978 / 4592$ & 64.8 & 63.5 to 66.2 \\
\hline Total & $2682 / 4945$ & 54.2 & 52.8 to 55.6 & $6030 / 8498$ & 71.0 & 70.0 to 71.9 \\
\hline \multicolumn{7}{|c|}{$\begin{array}{l}\text { AWAKE12 } \\
1 \text { night per year }\end{array}$} \\
\hline Males & $902 / 2600$ & 34.7 & 32.9 to 36.5 & $615 / 3906$ & 15.7 & 14.6 to 16.9 \\
\hline Females & $759 / 2345$ & 32.4 & 30.5 to 34.3 & $1156 / 4592$ & 25.2 & 23.9 to 26.4 \\
\hline Total & $1661 / 4945$ & 33.6 & 32.3 to 34.9 & $1771 / 8498$ & 20.8 & 20.0 to 21.7 \\
\hline \multicolumn{7}{|c|}{$\begin{array}{l}\text { AWAKE12 } \\
>1 \text { night per year }\end{array}$} \\
\hline Males & $312 / 2600$ & 12.0 & 10.8 to 13.2 & 239/3906 & 6.1 & 5.4 to 6.9 \\
\hline Females & $290 / 2345$ & 12.4 & 11.0 to 13.7 & $458 / 4592$ & 10.0 & 9.1 to 10.8 \\
\hline Total & $602 / 4945$ & 12.2 & 11.3 to 13.1 & $697 / 8498$ & 8.2 & 7.6 to 8.8 \\
\hline \multicolumn{7}{|l|}{ SPEECH12 } \\
\hline Males & $740 / 17010$ & 4.4 & 4.0 to 4.7 & $655 / 19726$ & 3.3 & 3.1 to 3.6 \\
\hline Females & $573 / 18180$ & 3.2 & 2.9 to 3.4 & $1304 / 21306$ & 6.1 & 5.8 to 6.4 \\
\hline Total & $1313 / 35190$ & 3.7 & 3.5 to 3.9 & 1959/41 032 & 4.8 & 4.6 to 5.0 \\
\hline \multicolumn{7}{|l|}{ ASTHMAEV } \\
\hline Males & $1176 / 17163$ & 6.9 & 6.5 to 7.2 & $1725 / 19818$ & 8.7 & 8.3 to 9.1 \\
\hline Females & $918 / 18345$ & 5.0 & 4.7 to 5.3 & $1822 / 21426$ & 8.5 & 8.1 to 8.9 \\
\hline Total & $2094 / 35508$ & 5.9 & 5.7 to 6.1 & $3547 / 41244$ & 8.6 & 8.3 to 8.9 \\
\hline \multicolumn{7}{|l|}{ ASTHDOC } \\
\hline Males & $1072 / 17011$ & 6.3 & 5.9 to 6.7 & $1338 / 19701$ & 6.8 & 6.4 to 7.1 \\
\hline Females & $819 / 18169$ & 4.5 & 4.2 to 4.8 & $1383 / 21292$ & 6.5 & 6.2 to 6.8 \\
\hline Total & $1891 / 35180$ & 5.4 & 5.1 to 5.6 & $2721 / 40993$ & 6.6 & 6.4 to 6.9 \\
\hline \multicolumn{7}{|l|}{ ASTHPLAN } \\
\hline Males & $872 / 17007$ & 5.1 & 4.8 to 5.5 & $655 / 19726$ & 4.9 & 4.6 to 5.2 \\
\hline Females & $654 / 18169$ & 3.6 & (3.3 to 3.9 ) & $1304 / 21306$ & 4.8 & 4.5 to 5.1 \\
\hline Total & $1526 / 35176$ & 4.3 & 4.1 to 4.6 & 1959/41032 & 4.9 & 4.7 to 5.1 \\
\hline
\end{tabular}

NA, Not available.

Figure 1A,B shows the prevalence of asthma symptoms by city ordered from the lowest to the highest altitude in school children males and female adolescents as they were more representative of the effect. The corresponding values of the Pearson correlations for WHEZEV, WHEZ12, SPEECH12 and ASTHMAEV with altitude were $-0.583(\mathrm{p}=0.023) ;-0.794(\mathrm{p}<0.001) ;-0.707$ $(\mathrm{p}=0.003) ;-0.427 \quad(\mathrm{p}=0.112)$ in school boys, and -0.652 $(\mathrm{p}=0.008) ;-0.747 \quad(\mathrm{p}=0.001) ;-0.646 \quad(\mathrm{p}=0.009) ;-0.341$ $(\mathrm{p}=0.231)$ in female adolescents.

\section{DISCUSSION}

The present study represents the most exhaustive effort to investigate the epidemiology of asthma in Mexico. Yet, it is not representative of all the Mexican regions, as only 
Table 2 Risk factors identified in the logistic regression in the 6-7 years group

\begin{tabular}{|c|c|c|c|c|}
\hline & \multicolumn{2}{|l|}{ Males 6-7 } & \multicolumn{2}{|l|}{ Females 6-7 } \\
\hline & OR (95\% Cl) & $P$ value & OR (95\% Cl) & $P$ value \\
\hline $\begin{array}{l}\text { In the past } 12 \text { months, has this child had a } \\
\text { problem with sneezing or a runny or blocked } \\
\text { nose when he/she DID NOT have a cold or a } \\
\text { influenza? }\end{array}$ & 3.592 (4.103 to 3.146$)$ & $<0.001$ & 4.484 (5.134 to 3.915$)$ & $<0.001$ \\
\hline Has this child ever had hay fever? & 1.453 (1.714 to 1.232$)$ & $<0.001$ & 1.263 (1.506 to 1.059$)$ & 0.009 \\
\hline $\begin{array}{l}\text { Has this child had this itchy rash at any time in } \\
\text { the past } 12 \text { months? }\end{array}$ & 1.735 (2.059 to 1.461$)$ & $<0.001$ & $1.396(1.669,1.168)$ & $<0.001$ \\
\hline $\begin{array}{l}\text { Did this child suffer from wheezing or whistling } \\
\text { in the chest during his/her first year of life? }\end{array}$ & 3.343 (3.804 to 2.937 ) & $<0.001$ & 3.849 (4.398 to 3.368$)$ & $<0.001$ \\
\hline $\begin{array}{l}\text { How many times a week does this child engage } \\
\text { in vigorous physical activity long enough to } \\
\text { make him/her breathe hard? Comparison never } \\
\text { or occasionally }\end{array}$ & & $<0.001$ & & 0.028 \\
\hline Once or twice per week & 0.871 (0.995 to 0.763$)$ & 0.042 & 0.939 (1.071 to 0.824$)$ & 0.349 \\
\hline Three or more times per week & 0.624 (0.737 to 0.528$)$ & $<0.001$ & 0.778 (0.935 to 0.648$)$ & 0.007 \\
\hline $\begin{array}{l}\text { Has this child ever been diagnosed with } \\
\text { pneumonia or bronchopneumonia? }\end{array}$ & 2.081 (2.485 to 1.743$)$ & $<0.001$ & 2.181 (2.628 to 1.809 ) & $<0.001$ \\
\hline $\begin{array}{l}\text { How often, on average, have you given this child } \\
\text { paracetamol? Comparison never }\end{array}$ & & $<0.001$ & & $<0.001$ \\
\hline At least once a year & 1.245 (1.541 to 1.005$)$ & 0.045 & 1.344 (1.696 to 1.064$)$ & 0.013 \\
\hline At least once per month & 2.099 (2.642 to 1.667$)$ & $<0.001$ & $2.325(2.972$ to 1.820$)$ & $<0.001$ \\
\hline Altitude (mamsl) Comparison <100m & & $<0.001$ & & $<0.001$ \\
\hline 100 to $<1000 m$ & 0.722 (0.876 to 0.595$)$ & 0.001 & 0.855 (1.040 to 0.702$)$ & 0.118 \\
\hline$>1000$ to $1500 \mathrm{~m}$ & 0.662 (0.789 to 0.555$)$ & $<0.001$ & 0.599 (0.719 to 0.499$)$ & $<0.001$ \\
\hline$>1500$ to $<2000 m$ & 0.546 (0.656 to 0.454$)$ & $<0.001$ & 0.708 (0.847 to 0.592$)$ & $<0.001$ \\
\hline$>2000$ to $2500 \mathrm{~m}$ & 0.686 (0.886 to 0.531$)$ & 0.004 & 0.769 (0.991 to 0.597$)$ & 0.042 \\
\hline$>2500 \mathrm{~m}$ & 0.426 (0.530 to 0.343 ) & $<0.001$ & 0.536 (0.665 to 0.432$)$ & $<0.001$ \\
\hline $\begin{array}{l}\text { Did you have a dog in your home during the first } \\
\text { year of this child's life? }\end{array}$ & 1.256 (1.418 to 1.112$)$ & $<0.001$ & & \\
\hline $\begin{array}{l}\text { In the past } 12 \text { months, how often, on average } \\
\text { did this child eat raw vegetables (green and } \\
\text { root)? Comparison never or only occasionally }\end{array}$ & & 0.008 & & \\
\hline Once or twice a week & 1.102 (1.264 to 0.961$)$ & 0.164 & & \\
\hline Most or all days & 1.301 (1.538 to 1.101$)$ & 0.002 & & \\
\hline $\begin{array}{l}\text { In the past } 12 \text { months, how often, on average } \\
\text { did this child eat butter? Comparison never or } \\
\text { only occasionally }\end{array}$ & & 0.026 & & \\
\hline Once or twice a week & 0.913 (1.052 to 0.793$)$ & 0.207 & & \\
\hline Most or all days & 0.658 (0.907 to 0.478$)$ & 0.011 & & \\
\hline $\begin{array}{l}\text { In the past } 12 \text { months, how often, on average } \\
\text { did this child eat nuts? Comparison never or } \\
\text { only occasionally }\end{array}$ & & 0.01 & & \\
\hline Once or twice a week & 0.823 (0.944 to 0.718$)$ & 0.005 & & \\
\hline Most or all days & 0.793 (1.035 to 0.607$)$ & 0.088 & & \\
\hline $\begin{array}{l}\text { Did this child's mother smoke during her } \\
\text { pregnancy with this child? }\end{array}$ & & & $1.441(2.026$ to 1.026$)$ & 0.035 \\
\hline $\begin{array}{l}\text { In this child's first year of life did this child have } \\
\text { regular (at least once a week) contact with farm } \\
\text { animals? }\end{array}$ & & & 1.263 (1.597 to 0.998 ) & 0.052 \\
\hline
\end{tabular}


Table 3 Risk factors identified in the logistic regression in the 13-14 years group

\begin{tabular}{|c|c|c|c|c|}
\hline & \multicolumn{2}{|l|}{ Males 13-14 } & \multicolumn{2}{|l|}{ Females 13-14 } \\
\hline & OR $(95 \% \mathrm{Cl})$ & $P$ value & OR $(95 \% \mathrm{Cl})$ & $P$ value \\
\hline $\begin{array}{l}\text { In the past } 12 \text { months, have you had a problem } \\
\text { with sneezing or a runny or blocked nose when } \\
\text { you DID NOT have a cold or a influenza? }\end{array}$ & 2.986 (3.354 to 2.659$)$ & $<0.001$ & 3.492 (3.825 to 3.188$)$ & $<0.001$ \\
\hline Have you ever had hay fever? & 2.144 (2.572 to 1.787$)$ & $<0.001$ & 2.080 (2.378 to 1.819$)$ & $<0.001$ \\
\hline $\begin{array}{l}\text { Have you had this itchy rash at any time in the } \\
\text { past } 12 \text { months? }\end{array}$ & $1.950(2.370$ to 1.604$)$ & $<0.001$ & $1.720(1.957$ to 1.511$)$ & $<0.001$ \\
\hline Have you ever had eczema? & $1.513(2.017$ to 1.135$)$ & 0.005 & $1.243(1.514$ to 1.020$)$ & 0.031 \\
\hline $\begin{array}{l}\text { How many times a week do you engage in } \\
\text { vigorous physical activity long enough to make } \\
\text { him/her breathe hard? Comparison never or } \\
\text { occasionally }\end{array}$ & & $<0.001$ & & $<0.001$ \\
\hline Once or twice per week & $1.240(1.436$ to 1.071$)$ & 0.004 & $1.304(1.446$ to 1.176$)$ & $<0.001$ \\
\hline Three or more times per week & $1.452(1.682$ to 1.253$)$ & $<0.001$ & 1.442 (1.627 to 1.277$)$ & $<0.001$ \\
\hline $\begin{array}{l}\text { In the past } 12 \text { months, how often, on average, } \\
\text { have you taken paracetamol for fever? } \\
\text { Comparison never }\end{array}$ & & $<0.001$ & & $<0.001$ \\
\hline At least once a year & 1.390 (1.639 to 1.178$)$ & $<0.001$ & $1.480(1.728$ to 1.268$)$ & $<0.001$ \\
\hline At least once per month & $2.242(2.676$ to 1.879$)$ & $<0.001$ & $2.312(2.706$ to 1.976$)$ & $<0.001$ \\
\hline Altitude (mamsl) comparison $<100 \mathrm{~m}$ & & $<0.001$ & & $<0.001$ \\
\hline 100 to $<1000 \mathrm{~m}$ & 0.937 (1.119 to 0.785$)$ & 0.474 & 0.916 (1.055 to 0.795$)$ & 0.225 \\
\hline$>1000$ to $1500 \mathrm{~m}$ & 0.874 (1.039 to 0.736$)$ & 0.127 & 1.015 (1.156 to 0.891$)$ & 0.826 \\
\hline$>1500$ to $<2000 m$ & 0.784 (0.929 to 0.661$)$ & 0.005 & $0.870(0.990$ to 0.764$)$ & 0.035 \\
\hline$>2000$ to $2500 \mathrm{~m}$ & 0.638 (0.817 to 0.498$)$ & $<0.001$ & 0.719 (0.869 to 0.595$)$ & 0.001 \\
\hline$>2500 \mathrm{~m}$ & 0.609 (0.743 to 0.499$)$ & $<0.001$ & 0.579 (0.687 to 0.489$)$ & $<0.001$ \\
\hline BMI class comparison normal weight & & 0.065 & & \\
\hline Underweight & 0.751 (1.069 to 0.528$)$ & 0.112 & & \\
\hline Overweight & 1.031 (1.194 to 0.891$)$ & 0.679 & & \\
\hline Obese & $1.177(1.380$ to 1.004$)$ & 0.044 & & \\
\hline $\begin{array}{l}\text { During normal week of } 7 \text { days, how many hours } \\
\text { a day ( } 24 \text { hours) do you spend on the computer } \\
\text { (including PlayStation, Smartphone, Tablet) or } \\
\text { on the internet (include chat, Facebook, games, } \\
\text { Twitter, YouTube)? Comparison less than } 1 \text { hour }\end{array}$ & & 0.01 & & \\
\hline 1 hour but less than 3 hours & $1.127(1.351$ to 0.940$)$ & 0.197 & & \\
\hline 3 hours but less than 5 hours & 1.220 (1.476 to 1.009$)$ & 0.04 & & \\
\hline 5 hours or more & $1.333(1.596$ to 1.113$)$ & 0.002 & & \\
\hline $\begin{array}{l}\text { How often do trucks pass through the street where } \\
\text { you live on weekdays? Comparison never }\end{array}$ & & 0.014 & & \\
\hline Seldom (not often) & 0.861 (1.009 to 0.734$)$ & 0.064 & & \\
\hline Frequently through the day & 0.981 (1.169 to 0.823$)$ & 0.827 & & \\
\hline Almost the whole day & 1.102 (1.316 to 0.923$)$ & 0.282 & & \\
\hline $\begin{array}{l}\text { In the past } 12 \text { months, how often, on average } \\
\text { did you eat seafood (including fish)? Comparison } \\
\text { never }\end{array}$ & & 0.006 & & \\
\hline Once or twice a week & 1.105 (1.250 to 0.976$)$ & 0.114 & & \\
\hline Most or all days & 1.524 (2.005 to 1.159$)$ & 0.003 & & \\
\hline
\end{tabular}

Continued 
Table 3 Continued

Males 13-14

Females 13-14

OR $(95 \% \mathrm{Cl})$

$P$ value

OR $(95 \% \mathrm{Cl})$

$P$ value

In the past 12 months, how often, on average

0.019

did you eat butter? Comparison never or only

occasionally

\begin{tabular}{|c|c|c|c|c|}
\hline Once or twice a week & 1.144 (1.291 to 1.014$)$ & 0.029 & & \\
\hline Most or all days & 1.267 (1.534 to 1.047$)$ & 0.015 & & \\
\hline $\begin{array}{l}\text { In the past } 12 \text { months, how often, on average did } \\
\text { you eat nuts? Comparison never }\end{array}$ & & & & 0.03 \\
\hline Once or twice a week & & & 1.086 (1.196 to 0.987$)$ & 0.092 \\
\hline Most or all days & & & 1.187 (1.358 to 1.037$)$ & 0.013 \\
\hline $\begin{array}{l}\text { In the past } 12 \text { months, how often, on average did } \\
\text { you eat sugar (including lolies, candies, sweets)? } \\
\text { Comparison never }\end{array}$ & & & & 0.001 \\
\hline Once or twice a week & & & 0.994 ( 1.113 to 0.889 ) & 0.923 \\
\hline Most or all days & & & 1.198 (1.347 to 1.066$)$ & 0.003 \\
\hline $\begin{array}{l}\text { In the past, have you smoked tobacco on a daily } \\
\text { basis, less than daily or not at all? Comparison not } \\
\text { at all }\end{array}$ & & & & $<0.001$ \\
\hline Less than daily & & & 1.678 (1.927 to 1.461$)$ & $<0.001$ \\
\hline Daily & & & 1.819 (3.665 to 0.903$)$ & 0.094 \\
\hline
\end{tabular}

BMI, body mass index.

14 cities participated in the study. Preliminary results had shown an increase in the prevalence of asthma in some centres in comparison to ISAAC Phase Three. In the school children group, there was an increase in the prevalence of 'wheeze ever' in North Mexico City, Toluca and Victoria City. The prevalence of asthma symptoms in North Mexico City, Victoria City and Mexicali was also higher, with a general increase of $1.8 \%$. In the adolescent group, there was an increased prevalence of 'wheeze ever' in North Mexico City and Mexicali; however, the prevalence was the same as reported in ISAAC Phase Three. ${ }^{10}$ Another study reported the results obtained from the GAN study in Mexico City and compared them with the ISAAC Phase Three study. Del-Rio-Navarro and collaborators observed that the prevalence of asthma symptoms increased by $3.8 \%$ in the group of school children and decreased one percent in the adolescents' group. ${ }^{11}$

ISAAC Phase Three also reported several parental and child characteristics associated with asthma symptoms in school children. Such factors included parental smoking $^{12}$; use of paracetamol in the first year of life as well as dose-dependent current use of paracetamol ${ }^{13}$; use of antibiotics in the first year of life ${ }^{14}$; dietary habits ${ }^{1516}$; overweight and obesity ${ }^{17}$ and sedentarism. ${ }^{18}$

Some studies analysed the complete databases from ISAAC Phase Three, searching for risk factors for asthma symptoms at an individual and school level. The most critical associations at individual and school levels in the school children group were current use of paracetamol (OR 2.06; 95\% CI 1.97 to 2.16), early life use of antibiotics (OR 1.65; 95\% CI 1.58 to 1.73 ) and open fire cooking (OR 1.44; 95\% CI 1.26 to 1.65). Meanwhile, in the adolescent's group, the most significant associations were the current use of paracetamol (OR 1.80; 95\% CI 1.75 to 1.86), open fire cooking (OR 1.32; 95\% CI 1.22 to 1.43 ) and maternal tobacco use (OR $1.23 ; 95 \%$ CI 1.18 to 1.27$){ }^{19}$

In the present study, the main risk factors for asthma symptoms in school children and adolescents were the presence of symptoms and diagnosis of rhinitis and eczema, the use of paracetamol, and the presence of smoking in the female adolescent's group. Interestingly, our study reported a negative association between altitude and asthma symptoms in both age groups.

These results agree with what has been published in a recent study carried out in children in Angola, where the ISAAC study was used as a reference and reported that asthma symptoms were significantly associated with paracetamol use (OR 3.94; 95\% CI 2.29 to $6.81 \mathrm{p}<0.001$ ), antibiotic uptake in the first year of life (OR 2.54; $95 \%$ CI 1.97 to $3.29 \mathrm{p}<0.001$ ), allergic rhinitis symptoms (OR 8.74; $95 \%$ CI 7.06 to $10.82 \mathrm{p}<0.001)$ and itchy rash in the past 12 months (OR 4.40; $95 \%$ CI 3.56 to $5.44 \mathrm{p}<0.001) .^{20}$ The association between paracetamol intake and those conditions may be due to the depletion of glutathione, a key antioxidant of the airways, as proposed by Cheelo et $a l^{21}$

On the other hand, associations between asthma outcomes in children and secondhand smoking have been described in the literature with exposures associated 


\section{A}

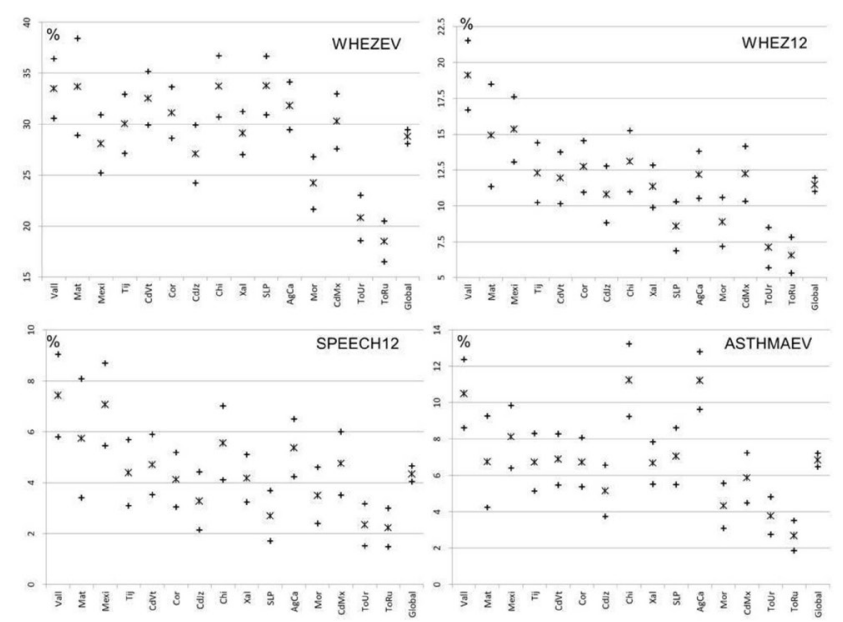

B

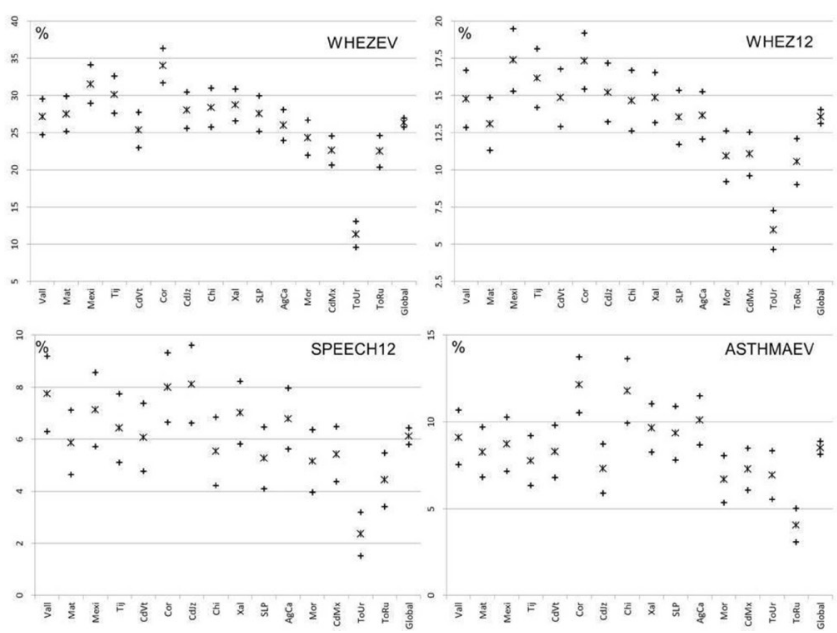

Figure 1 (A) Prevalence of asthma variables in male school children. (B) Prevalence of asthma in women. Point prevalences are represented by the asterisks and 95\% Cl by crosses for each city. Centres: AgCa, Aguascalientes; CdJZ, Juarez City; CdMx, Mexico City; CdVt, Victoria City; Chi, Chihuahua City, Cor, Córdoba; Mat, Matamoros; Mexi, Mexicali; Mor, Morelia; SLP, San Luis Potosi; Tij, Tijuana; ToRu, Rural Toluca; ToUr, Urban Toluca; Vall, Puerto Vallarta; Xal, Xalapa.

with an increased risk of asthma, asthma exacerbations, wheezing and reduced lung function, as reported in ISAAC Phase Three. ${ }^{22}{ }^{23}$ Tobacco smoke is a mixture of compounds, including carbon and nitrogen oxides, particulate matter, nitrosamines and other chemicals, many of which are toxicants that can induce inflammation and altered immune responses. ${ }^{24}$

According to our results, having the habit of smoking increased the risk of asthma symptoms in female adolescents. This has been reported previously in other countries. For example, the Canadian National Population Health Survey reported that female smokers had a $70 \%$ higher prevalence rate of asthma compared with nonsmokers, and the interaction between smoking and gender was particularly evident among women aged less than 25 years $(\text { OR } 2.18)^{25}$

Mexico, like other Latin American countries, has suffered at least 25 years of economic stagnation, increasing inequalities and decreasing wages. This economic context has marked the course of the tobacco epidemic, which has been reflected with the consumption of tobacco in adolescents and young people under 25 years of age. ${ }^{26}$

Similarly, the tendency of adolescents to present with exacerbations of asthma symptoms during adolescence should be considered. It has been argued that the increment of sex hormones and/or to differences in gender-specific responses to environmental or occupational exposures make them susceptible to presenting with bronchial symptoms. ${ }^{27}$ Tantisira and collaborators reported in a large cohort of children that after the age of 11 years, the provocative concentration of methacholine necessary to cause a $20 \%$ decrease in forced expiratory volume in $1 \mathrm{~s}\left(\mathrm{PC}_{20}\right)$ increased in men, suggesting an improvement in airway responsiveness during puberty in men but not in women. ${ }^{28}$ Sex hormones have a wide variety of effects beyond the $\beta 2$ adrenoreceptor. For example, they alter the function of epithelial cells. The progesterone receptor is expressed in the epithelium of the airways, and progesterone inhibits the beat frequency of the cilia, which can affect mucociliary clearance during the menstrual cycle among women. ${ }^{29}$ At the same time, experimental studies suggest that testosterone has a relaxing effect on precontracted tracheal smooth muscle and androgens may modulate the density of choline receptors. ${ }^{30}$ Interestingly, worldwide studies had reported that women with premenstrual asthma are at higher risk for severe asthma, required more corticosteroids therapy, and have a higher risk for emergency room visits and admission to the intensive care unit. ${ }^{31}$

In recent years, the increase in the prevalence of multimorbidity of allergic diseases in paediatric patients has been evident. As an example of the above, Dogru reported that $50 \%$ of patients under the age of 10 with mild to severe allergic rhinitis also had a asthma diagnosis. ${ }^{32}$ Similarly, the ARIA guidelines had reported a $10 \%-14 \%$ prevalence of asthma in adult patients with allergic rhinitis. ${ }^{33}$ In line with this, our results showed that patients with symptoms of rhinitis had twice the risk of developing asthma symptoms. Additionally, other studies have reported that the presence of eczema during the first year of life and preschool, increases the risk of wheezing at school age by three times. ${ }^{34}$ Following this, it could be possible to infer that patients, who show eczema or rhinitis symptoms from the first year of life, have a higher risk of asthma symptoms at school age which persist during adolescence.

In contrast, other ISAAC based studies focused on the effect of a healthy lifestyle index in the prevalence of asthma, rhinoconjunctivitis and eczema. The healthy lifestyle index was the combination of five factors: the absence of parental smoking, following a Mediterranean 
diet, average healthy body mass index, high physical activity and consequent non-sedentary behaviour. The combination of $4-5$ of these factors may diminish the risk of current wheezing by $13 \%$ (OR $0.87 ; 95 \%$ CI 0.84 to 0.89 ). The management of these factors as a healthy lifestyle index could reduce the burden of asthma by $16 \%{ }^{35}$

Similarly, our results in school children showed that vigorous physical activity at least once or twice a week is a protective factor to prevent wheezing. At the same time, a history of maternal smoking during pregnancy and obesity (reported in the male adolescent's group) increases the risk of asthma symptoms.

On the other hand, previous studies using the database of Mexican National Social Security found that altitude higher than $1500 \mathrm{~m}$ is a major factor on the incidence of asthma, with the new-onset asthma risk decreasing as altitude increases. ${ }^{36}$ Vargas et al demonstrated that asthma incidence rates tended to be higher in centres located on or near the coast. However, some centres in the northern region of Mexico also had high asthma rates. According to their study, asthma incidence was maintained relatively constant up to an altitude of $\sim 1500 \mathrm{~m}$, with a progressive decline after that, with a statistically significant change at an altitude of $1539 \mathrm{~m} .{ }^{36}$ The above agrees with our results, mainly in the adolescent group, where it is observed that the risk of presenting with asthma symptoms decreases as the altitude increases from $1500 \mathrm{~m}$ above sea level. Additionally, a clinical trial on high altitude climate treatment for severe asthma for 12 months found a decrease of $34 \%$ in the number of exacerbations and $36 \%$ in the hospitalisations in comparison to the previous year. These findings support the possible protective effect of high altitude in the incidence of asthma as well as in the control of the symptoms. ${ }^{38}$ The hypothesis regarding altitude, besides less pollution, is that it significantly reduces the level of exhaled nitric oxide, increases blood levels of interleukin 10 (a cytokine with powerful anti-inflammatory properties) and decreases the concentration of interferon- $\gamma$, responsible for inflammation of the local airways. ${ }^{39}$

An ISAAC Phase Three analysis of all available centres in Latin America (56 centres in 17 countries) studied the relationship between asthma symptoms and geographic characteristics in adolescents. Regarding altitude, there was a small but significant inverse correlation between altitude and asthma symptoms $(\mathrm{r}=-0.27, \mathrm{p}=0.04)$. However, no significant correlation was found when the centres with higher altitude $(>2000 \mathrm{~m})$ were excluded for the analysis. ${ }^{7}$ This suggests that there are other factors, in addition to altitude, such as female predisposition and environmental factors that could increase the prevalence of asthma symptoms in the last decade.

In this sense, a Mexican study in children explored the prevalence of asthma, allergic rhinitis and atopic dermatitis and the possible related factors identified with a rural environment following the ISAAC methods. Nonetheless, it could not demonstrate that a rural environment protects against asthma or other allergic diseases. ${ }^{40}$ In the present study, contact with farm animals in the first year of life was only a marginal risk factor for developing asthma symptoms in school girls. Additionally, comparing urban and rural Toluca centres, the prevalences of asthma symptoms were similar in both locations in school children. Studies are beginning to demonstrate rural paediatric asthma prevalence to be similar to urban. ${ }^{41}$ Yet, in the adolescent group, women from the rural centre had a lower prevalence of wheeze ever in comparison to participants in the urban centre. This could be explained as the outside air quality in rural areas is, in general, better than in urban areas, and children and adolescents may experience less exposure to pollutants associated with worse asthma outcomes (such as diesel exhaust).$^{42}$ Urban children are more likely to live in multi-unit housing, which is associated with cockroach, rodent, and dust mite allergen exposure, which are often known to cause allergic sensitisation and asthma exacerbations. ${ }^{43}$

Finally, another aspect to consider is asthma underdiagnosis of $50 \%$ as reported in this study. Asthma underdiagnosis is a public health problem in multiple countries. For example, van Gent et al reported that of a sample of 1614 Dutch children, 130 (8\%) had undiagnosed asthma and $81(5 \%)$ had diagnosed asthma, suggesting that in Dutch school children $62 \%$ of subjects with current asthma were undiagnosed.$^{43}$ Generally, population-based studies indicate that $7 \%-10 \%$ of the adult and paediatric population have current asthma, and in those with current asthma, between $20 \%$ and $73 \%$ remain undiagnosed. ${ }^{44}$ Is widely known that the diagnosis and treatment of allergic diseases depend to a great extent on the education of the first contact doctor and the family members to detect symptoms in their mild to moderate manifestation and avoid a negative impact on the patient's quality of life. Therefore, it is essential to invest in this type of study at an international level, so that we can analyse multiple factors that may contribute to developing asthma symptoms, and sustain national health strategies for diagnosis and management of allergic diseases to improve the quality of life of patients at any age. ${ }^{8}$

\section{CONCLUSIONS}

In the present study, we show overall, increases in the prevalence of asthma symptoms and severity in 14 cities across Mexico in the last 15 years, compared with the ISAAC Phase Three Study. The most important risk factors for asthma symptoms were the presence of allergic symptoms and diagnosis of rhinitis and eczema, as well as the current or past use of paracetamol. On the other hand, sea level altitude higher than $1500 \mathrm{~m}$ was seen as a protective factor. The urban and rural centres of Toluca had a lower prevalence of asthma symptoms compared with the cities under 1000 mamsl. The identification of risk factors and their pattern could help implement strategies to mitigate the incidence of asthma such as a reduction of paracetamol exposure in atopic families, as well as residence change, when possible, in selected patients. 
Further studies are necessary to explore the impact of urban and rural environments in the prevalence of asthma and other allergic diseases.

\section{LIMITATIONS}

This multicentre cross-sectional study has limitations typical of an observational study. However, the GAN methodology, following the ISAAC methodology is an internationally recognised method that can successfully identify the prevalence of symptoms related to allergic diseases, which have increased in the last decade worldwide. The information was obtained with a standard methodology with a previously validated instrument and with a high response rate from all the centres involved. This study allows us to identify important associations and potential risk factors by sex and age along with access to environmental factors like altitude as a possible modulating factor for current wheezing in the Mexican population. This opens the opportunity to carry out studies that allow analysing the intrinsic and environmental factors related to the increase in the prevalence of asthma in different areas of the world. It represents an opportunity area to develop national strategies necessary to detect and care for the population at risk with asthma symptoms and other allergic diseases.

\section{Author affiliations}

${ }^{1}$ Allergy and Immunology, Hospital Infantil de México Federico Gomez, Mexico City, Mexico

${ }^{2}$ Allergy and Immunology, Hospital Infantil de Tamaulipas, Ciudad Victoria, Mexico

${ }^{3}$ Paediatrics: Child and Youth Health, The University of Auckland, Auckland, New Zealand

${ }^{4}$ Paediatric Allergy and Pulmonology Units ‘Virgen de la Arrixaca' University Children's Hospital, University of Murcia, Universidad de Murcia, Murcia,

Spain

${ }^{5}$ Allergy and Immunology, Clínica de Asma-Alergia, Mexicali, Mexico

${ }^{6}$ Allergy and Immunology, Instituto Mexicano del Seguro Social, San Luis Potosí, San Luis Potosí, Mexico

${ }^{7}$ Allergy and Immunology, Hospital General de Tijuana, Tijuana, Mexico

${ }^{8}$ Allergy and Immunology, Centro de Investigación, Diagnóstico y Tratamiento de Asma y Alergias, Toluca, Estado de México, Mexico

${ }^{9}$ Allergy and Immunology, Hospital Ángeles Chihuahua, Chihuahua, Mexico

${ }^{10}$ Allergy and Immunology, Hospital Ángeles Ciudad Juárez, Chihuahua, Mexico

${ }^{11}$ Allergy and Immunology, CRIT Michoacán, Morelia, Michoacán, Mexico

${ }^{12}$ Allergy and Immunology, Hospital Ángeles Xalapa, Xalapa, Veracruz, Mexico

${ }^{13}$ Allergy and Immunology, Universidad Veracruzana, Córdoba, Veracruz,

\section{Mexico}

${ }^{14}$ Allergy and Immunology, Private practice, Puerto Vallarta, Jalisco, Mexico

${ }^{15}$ Allergy and Immunology, Benemérita Universidad Autónoma de

Aguascalientes, Aguascalientes, Mexico

${ }^{16}$ Allergy and Immunology, Hospital General de Matamoros, Matamoros, Mexico

Acknowledgements We thank all the school children, adolescents and parents who collaborated in the GAN study, for obtaining information and updating the prevalence of asthma. All the authors involved in this article who contributed to the design, elaboration, writing and analysis of this work. We appreciate the financial support of the Mexican College of Pediatricians Specializing in Allergy and Clinical Immunology (COMPEDIA) to print the questionnaires used for this important project. Likewise, we would like to thank the support of Dr Innes Asher and her team of collaborators, for their direction in preparing this study, as well as for their support for the inclusion of Mexico in this important international study. Finally, we thank the support of Dr Virginia Pérez Hernández, Axel Arturo Berber-Del-Río, Dr Joaquín Alberto Alejandro Pimentel Hayashi, Dr Yolanda Rodríguez Galván, Dra Laura Alicia Sacre, Dr Ricardo Regules García, Dr Juan José Luis Sienra Monge and Dr Jaime Mariano Del Río Chivardi for their contribution to the revision and editing of this article.

Collaborators The GAN Phase I group: 0J Saucedo-Ramírez (Mexico City, Mexico), V Merida-Palacio (Mexicali, Mexico), BC Ramos-García (San Luis Potosí, Mexico), AJ Escalante-Dominguez (Tijuana, Mexico), F Linares-Zapien (Toluca, Mexico), HL Moreno-Gardea (Chihuahua, Mexico), G Ochoa-Lopez (Ciudad Juárez, Mexico), L0 Hernández-Mondragón (Morelia, Mexico), JS Lozano-Saenz (Xalapa, Mexico), JA Sacre-Hazouri (Córdoba, México), A Juan-Pineda (Puerto Vallarta, Mexico), MG Sánchez Coronel (Aguascalientes, Mexico), N Rodríguez-Pérez (Tamaulipas, Mexico), MJ Ambriz-Moreno (Tamaulipas, Mexico).

Contributors BED-R-N, NRN, EMNR, RG-A, PE and LG-M: study conception, design, acquisition of data and drafting the manuscript. $A B$ : statistical analysis. OJSR, VJMP, BDCRG, AJED, FJLZ, LGM, GGOL, LOHM, JSLS, JASH, AJP, MGSC, NRP, MdJAM: data acquisition and drafted the initial version of the article. All authors contributed to data interpretation and read, commented on and approved the final version.

Funding The authors have not declared a specific grant for this research from any funding agency in the public, commercial or not-for-profit sectors.

Competing interests None declared.

Patient and public involvement Patients and/or the public were not involved in the design, or conduct, or reporting, or dissemination plans of this research.

Patient consent for publication Not required.

Ethics approval The present study was approved by the Ethics, Research, and Biosafety committees of the Hospital Infantil de México Federico Gómez (HIMFG, protocol HIM/2016/065) by the guidelines of the institution and according to the Mexican law, was valid to all participant centres.

Provenance and peer review Not commissioned; externally peer reviewed.

Data availability statement Data are available in a public, open access repository. All data relevant to the study are included in the article or uploaded as supplementary information. Information regarding this article can be requested from Dra Blanca Estela Del Río Navarro at blancadelrionavarro@gmail.com.

Open access This is an open access article distributed in accordance with the Creative Commons Attribution Non Commercial (CC BY-NC 4.0) license, which permits others to distribute, remix, adapt, build upon this work non-commercially, and license their derivative works on different terms, provided the original work is properly cited, appropriate credit is given, any changes made indicated, and the use is non-commercial. See: http://creativecommons.org/licenses/by-nc/4.0/.

ORCID iD

Nayely Reyes-Noriega http://orcid.org/0000-0002-1701-7517

\section{REFERENCES}

1 The Union. The global asthma report 2018. Auckland, New Zealand: Global Asthma Network, 2018.

2 GBD 2016 Causes of Death Collaborators. Global, regional, and national age-sex specific mortality for 264 causes of death, 19802016: a systematic analysis for the global burden of disease study 2016. Lancet 2017:390:1151-210.

3 Bahadori K, Doyle-Waters MM, Marra C, et al. Economic burden of asthma: a systematic review. BMC Pulm Med 2009;9:1-16.

4 Asher Ml, Strachan DP, Pearce N, et al. The Isaac story: the International study of asthma and allergies in childhood. Auckland, New Zealand: The International Study of Asthma and Allergies in Childhood, 2011.

5 Ellwood P, Asher MI, Billo NE, et al. The global asthma network rationale and methods for phase I global surveillance: prevalence, severity, management and risk factors. Eur Respir J 2017;49. doi:10.1183/13993003.01605-2016. [Epub ahead of print: 11 Jan 2017].

6 Mallol J, Solé D, Baeza-Bacab M, et al. Regional variation in asthma symptom prevalence in Latin American children. J Asthma 2010:47:644-50.

7 Del-Rio-Navarro B, Berber A, Blandón-Vijil V, et al. Identification of asthma risk factors in Mexico City in an international study of asthma and allergy in childhood survey. Allergy Asthma proc 2006;27:325-33.

8 Ellwood $\mathrm{P}$, Williams $\mathrm{H}$, Ait-Khaled $\mathrm{N}$, et al. Translation of questions: the International study of asthma and allergies in childhood (Isaac) experience. Int J Tuberc Lung Dis 2009;13:1174-82. 
9 Ellwood P, Asher MI, Stewart AW, et al. The challenges of replicating the methodology between phases I and III of the Isaac programme. Int J Tuberc Lung Dis 2012;16:687-93.

10 Asher Ml, Montefort S, Björkstén B, et al. Worldwide time trends in the prevalence of symptoms of asthma, allergic rhinoconjunctivitis, and eczema in childhood: Isaac phases one and three repeat multicountry cross-sectional surveys. Lancet 2006;368:733-43.

11 Del-Rio-Navarro BE, Navarrete-Rodríguez EM, Berber A, et al. The burden of asthma in an inner-city area: A historical review 10 years after Isaac. World Allergy Organ J 2020;13:100092.

12 Mitchell EA, Beasley R, Keil U, et al. The association between tobacco and the risk of asthma, rhinoconjunctivitis and eczema in children and adolescents: analyses from phase three of the Isaac programme. Thorax 2012;67:941-9.

13 Beasley R, Clayton T, Crane J, et al. Association between paracetamol use in infancy and childhood, and risk of asthma, rhinoconjunctivitis, and eczema in children aged 6-7 years: analysis from phase three of the Isaac programme. Lancet 2008;372:1039-48.

14 Muc M, Padez C, Pinto AM. Exposure to paracetamol and antibiotics in early life and elevated risk of asthma in childhood. Adv Exp Med Biol 2013;788:393-400.

15 Ellwood P, Asher MI, García-Marcos L, et al. Do fast foods cause asthma, rhinoconjunctivitis and eczema? global findings from the International study of asthma and allergies in childhood (Isaac) phase three. Thorax 2013;68:351-60.

16 Castro-Rodriguez JA, Garcia-Marcos L. What are the effects of a Mediterranean diet on allergies and asthma in children? Front Pediatr 2017;5:72.

17 Weinmayr G, Forastiere F, Büchele G, et al. Overweight/obesity and respiratory and allergic disease in children: International study of asthma and allergies in childhood (Isaac) phase two. PLoS One 2014;9:e113996.

18 Mitchell EA, Beasley R, Björkstén B, et al. The association between $\mathrm{BMI}$, vigorous physical activity and television viewing and the risk of symptoms of asthma, rhinoconjunctivitis and eczema in children and adolescents: Isaac phase three. Clin Exp Allergy 2013;43:73-84.

19 Silverwood RJ, Rutter CE, Mitchell EA, et al. Are environmental risk factors for current wheeze in the International study of asthma and allergies in childhood (Isaac) phase three due to reverse causation? Clin Exp Allergy 2019;49:430-41.

20 Arrais M, Lulua O, Quifica F, et al. Prevalence of asthma, allergic rhinitis and eczema in 6-7-year-old schoolchildren from Luanda, Angola. Allergol Immunopathol 2019;47:523-34.

21 Cheelo M, Lodge CJ, Dharmage SC, et al. Paracetamol exposure in pregnancy and early childhood and development of childhood asthma: a systematic review and meta-analysis. Arch Dis Child 2015;100:81-9.

22 US Department of Health and Human Services. The health consequences of Smoking-50 years of progress. A report of the surgeon General. Atlanta, GA: US Department of Health and Human Services, Centers for Disease Control and Prevention, National Center for Chronic Disease Prevention and Health Promotion, Office on Smoking and Health, 2014.

23 Gilliland FD, Li YF, Peters JM. Effects of maternal smoking during pregnancy and environmental tobacco smoke on asthma and wheezing in children. Am J Respir Crit Care Med 2001;163:429-36.

24 US Department of Health and Human Services. The health consequences of involuntary exposure to tobacco smoke: a report of the surgeon General. Washington, DC, 2006.

25 Chen Y, Dales R, Krewski D, et al. Increased effects of smoking and obesity on asthma among female Canadians: the
National population health survey, 1994-1995. Am J Epidemiol 1999;150:255-62.

26 Franco-Marina F. Adult smoking trends in Mexico: an analysis of the Mexican national addiction surveys. Salud Pública de México 2007; 49:s137-46.

27 Zein JG, Erzurum SC. Asthma is different in women. Curr Allergy Asthma Rep 2015;15:28.

28 Tantisira KG, Colvin R, Tonascia J, et al. Airway responsiveness in mild to moderate childhood asthma: sex influences on the natural history. Am J Respir Crit Care Med 2008;178:325-31.

29 Jain R, Ray JM, Pan J-hong, et al. Sex hormone-dependent regulation of cilia beat frequency in airway epithelium. Am J Respir Cell Mol Biol 2012;46:446-53.

30 Kouloumenta V, Hatziefthimiou A, Paraskeva E, et al. Non-Genomic effect of testosterone on airway smooth muscle. Br J Pharmacol 2006;149:1083-91.

31 Rao CK, Moore CG, Bleecker E, et al. Characteristics of perimenstrual asthma and its relation to asthma severity and control: data from the severe asthma research program. Chest 2013;143:984-92.

32 Dogru M. Investigation of asthma comorbidity in children with different severities of allergic rhinitis. Am J Rhinol Allergy 2016;30:186-9.

33 Klimek L, Bachert C, Pfaar O, et al. Aria guideline 2019: treatment of allergic rhinitis in the German health system. Allergol Select 2019;3:22-50.

34 Arshad SH, Kurukulaaratchy RJ, Fenn M, et al. Early life risk factors for current wheeze, asthma, and bronchial hyperresponsiveness at 10 years of age. Chest 2005;127:502-8.

35 Morales E, Strachan D, Asher I, et al. Combined impact of healthy lifestyle factors on risk of asthma, rhinoconjunctivitis and eczema in school children: Isaac phase III. Thorax 2019;74:531-8.

36 Vargas MH, Sienra-Monge JJ, Díaz-Mejía G, et al. Asthma and geographical altitude: an inverse relationship in Mexico. $J$ Asthma 1999;36:511-7.

37 Vargas MH, Becerril-Ángeles M, Medina-Reyes IS, et al. Altitude above $1500 \mathrm{~m}$ is a major determinant of asthma incidence. An ecological study. Respir Med 2018;135:1-7.

38 Fieten KB, Rijssenbeek-Nouwens LH, Hashimoto S, et al. Less exacerbations and sustained asthma control 12 months after high altitude climate treatment for severe asthma. Allergy 2019;74:628-30.

39 Oğhan F, Erdim İbrahim, Erdim I. Associations among high altitude, allergic rhinitis, and bronchial hyperreactivity. ENT Updates 2017;7:47-52.

40 Bedolla-Barajas M, Javier Ramírez-Cervantes F, Morales-Romero J, et al. A rural environment does not protect against asthma or other allergic diseases amongst Mexican children. Allergol Immunopathol 2018;46:31-8.

41 Estrada RD, Ownby DR. Rural asthma: current understanding of prevalence, patterns, and interventions for children and adolescents. Curr Allergy Asthma Rep 2017;17:37.

42 Beck AF, Huang B, Kercsmar CM, et al. Allergen sensitization profiles in a population-based cohort of children hospitalized for asthma. Ann Am Thorac Soc 2015;12:376-84.

43 van Gent R, van Essen LEM, Rovers MM, et al. Quality of life in children with undiagnosed and diagnosed asthma. Eur J Pediatr 2007;166:843-8.

44 Aaron SD, Boulet LP, Reddel HK, et al. Underdiagnosis and overdiagnosis of asthma. Am J Respir Crit Care Med 2018;198:1012-20. 